Original Article

\title{
Evaluation of vegetables grown in dry mountainous regions for soil transmitted helminths contamination
}

\author{
Avaliação de vegetais para contaminação por helmintos transmitida pelo solo em \\ quatro distritos da divisão de Malakand: noroeste do Paquistão
}

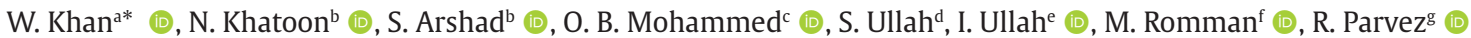 \\ and A. H. Mahmoudc (D) \\ aUniversity of Malakand, Department of Zoology, Lower Dir, Pakistan \\ bUniversity of Karachi-Karachi, Department of Zoology, Karachi, Pakistan \\ 'King Saud University, College of Science, Department Zoology, Riyadh, Saudi Arabia \\ dUniversity of Swabi, Department of Zoology, Swabi, , Pakistan \\ eKarakoram International University, Department of Biological Science, Ghizer Campus, Gilgit Baltistan, Pakistan \\ University of Chitral, Department of Botany, Chitral, Pakistan \\ ${ }^{g}$ Government Girls Degree College Dargai, Department of Botany, Malakand, KP, Pakistan
}

\begin{abstract}
Infection caused by geo-helminth parasites are called geohelminthiasis are one of the global health problems. Vegetables eaten raw is the principal source of transmission of geo-helminth parasites. Pakistani people believe that eating raw vegetables are a significant source to get important vitamins and minerals. Based on the high incidence of pathogenic parasites and cultivating different vegetable types in the study areas, we conducted this study to evaluate the geo-helminth contamination of raw vegetables in northwest Khyber Pakhtunkhwa, Pakistan. This is a descriptive study comprised, 1942 samples of 25 various types of vegetables. The samples were examined in physiological saline solution using sedimentation and centrifugation methods. The findings were analyzed by Graph-Pad version 5. P value less than $0.05(95 \% \mathrm{CI})$ was considered significant. Results showed that $16.5 \%(\mathrm{n}=322)$ of all vegetables were contaminated with one or more type of geo-helminth parasites. Garlic was the highest (35\%) and cauliflower the lowest (4\%) contaminated samples respectively. Ascaris lumbricoides was the most common geohelminth found followed by hook worm species while Trichuris trichura was the least in all the vegetable samples. Leafy vegetables were highly contaminated $25.3 \%$ than vegetables with root parts $21.2 \%$ and fruity $9.09 \%$. More than half of the contaminated vegetables were contaminated with single species of geo-helminth $(\mathrm{P}<0.05)$ while less than half with multiple types of geo-helminth contamination. Ninety two vegetables samples were contaminated with 2 species of parasites $(\mathrm{P}<0.05)$ and 45 with $3(\mathrm{P}>0.05)$ species of geo-helminth parasites. Education level of vendors and means of display were not significantly associated while types of vegetable used were significantly associated with the prevalence of parasites. The findings of this study provide evidence that consumption of raw vegetable has a high risk of acquiring geo-helminth infections. The authors believe that preventing the human to enter to the vegetable farmland for defecation, avoiding the irrigation of agricultural fields via night soil, and educating the people on proper washing and cooking of vegetables may be useful in reducing parasitic infections.

Keywords: raw vegetables, geo-helminths, helminths of public health significance, parasitic contamination, poor sanitation.
\end{abstract}

\section{Resumo}

As infecções causadas por parasitas geo-helmínticos são chamados de geohelmintíases e são um dos problemas de saúde globais. Os vegetais comidos crus são a principal fonte de transmissão dos parasitas geo-helmínticos. O povo paquistanês acredita que comer vegetais crus é uma fonte significativa para obter vitaminas e minerais importantes. Com base na alta incidência de parasitas patogênicos e no cultivo de diferentes tipos de vegetais nas áreas de estudo, conduzimos este estudo para avaliar a contaminação por geo-helmintos de vegetais crus no noroeste de Khyber Pakhtunkhwa, Paquistão. Trata-se de um estudo descritivo composto por 1942 amostras de 25 tipos diversos de vegetais. As amostras foram examinadas em solução salina fisiológica utilizando métodos de sedimentação e centrifugação. Os achados foram analisados pelo Graph-Pad versão 5 . 0 valor de P menor que 0,05 (IC 95\%) foi considerado significativo. Os resultados mostraram que $16,5 \%(n=322)$ de todas as hortaliças estavam contaminadas com um ou mais tipos de parasitas geo-helmínticos. O alho foi a amostra mais contaminada (35\%) e a couve-flor a menos (4\%), respectivamente. Ascaris lumbricoides foi o geo-helmíntico mais comum encontrado,

*e-mail: walikhan.pk@gmail.com

Received: June 1, 2020 - Accepted: August 12, 2020

This is an Open Access article distributed under the terms of the Creative Commons Attribution License, which permits unrestricted use, distribution, and reproduction in any medium, provided the original work is properly cited. 
seguido por espécies de verme-anzol, enquanto Trichuris trichura foi o menos encontrado em todas as amostras de vegetais. Os vegetais folhosos foram altamente contaminados $25,3 \%$ do que os vegetais com partes de raiz $21,2 \%$ e frutados 9,09\%. Mais da metade dos vegetais contaminados estavam contaminados com uma única espécie de geo-helmintos $(\mathrm{P}<0,05)$, enquanto menos da metade com vários tipos de contaminação com geo-helmintos. Noventa e duas amostras de vegetais estavam contaminadas com 2 espécies de parasitas $(P<0,05)$ e 45 com 3 $(P>0,05)$ espécies de parasitas geo-helmínticos. O nível de escolaridade dos vendedores e os meios de exibição não foram significativamente associados, enquanto os tipos de vegetais usados foram significativamente associados à prevalência de parasitas. Os resultados deste estudo fornecem evidências de que o consumo de vegetais crus tem um alto risco de adquirir infecções por geo-helmintos. Os autores acreditam que impedir que o ser humano entre na terra de hortaliças para defecação, evitar a irrigação de campos agrícolas via solo noturno e educar as pessoas sobre a lavagem e cozimento adequados de vegetais pode ser útil na redução de infecções parasitárias.

Palavras-chave: vegetais crus, geo-helmintos, helmintos de importância para a saúde pública, contaminação parasitária, saneamento deficiente.

\section{Introduction}

Soil-transmitted helminthiasis is one of the most reluctant global health problems, against which the people have no satisfactory defense. Above one billion people have been infected by one type of helminth (MascariniSerra, 2011). Almost 819 million people have been infected by Ascaris lumbricoides, 439 million by hookworm, and 465 million by Trichuris trichiura (Pullan et al., 2014) throughout the world. Sub-Saharan Africa, America and East Asia are the endemic areas (DGDP, 2013). Disease caused by soil-transmitted helminthes can lead to declining health conditions, lowering nutritional status of the population and intelligence, productivity, causing loss of carbohydrates, protein and blood, lowering the quality of human resources, so many causes economic losses and much more (Shumbej et al., 2015; Suchdev et al., 2014). Due to the consumption of raw vegetables outbreaks of human infections have occurred in the past decade (Blackburn and McClure, 2002). Studies indicated that humans subjects that consumes uncooked or improperly washed vegetables and fruits may be infected with Ascaris lumbricoides, hookworm, and Trichuris trichiura (Kozan et al., 2005). Soil transmitted helminthes require soil for development of immature stages i.e infective eggs in case of ascaris and trichuris and larvae in case of hookworm species to be transmitted to their hosts through different agencies like soil, water and others. It is therefore named soil transmitted helminthes or STH.

Pakistan has a wide range of climatic conditions which makes the environment suitable for developmental stages of all the three geo-helminth parasites. According to a survey on soil-transmitted helminthiasis conducted by WHO (2017) in Pakistan, the highest prevalence was $37.5 \%$ in Northern Dry Mountains (parts of northern KPK, northern Federally Administered Tribal Areas and GilgitBaltistan). The inhabitants of the Barani Lands (parts of northern Punjab, Islamabad Capital Territory, and two noncontiguous regions of KPK) were reported to be infected $25.3 \%$. The lower prevalence rates of soil transmitted helminthes was ranging from $12.2 \%$ in the Wet Mountains (Azad Jammu \& Kashmir and parts of north eastern KPK), while no positive case was reported for the Western Dry Mountains (north-eastern Balochistan, southern FATA and central KPK). The environmental factors, socio-economic condition and personal hygiene of inhabitants of northern parts of Pakistan favors STHs.
According to a baseline survey of WHO (2017) on soil-transmitted helminthiasis in Pakistan, the highest prevalence was reported in northern parts of Khyber Pakhtunkhwa, northern Federally Administered Tribal Areas and Gilgit-Baltistan. They use raw vegetables containing pesticide contamination risk or helminth eggs. Farmers of these areas also frequently use night soil to increase soil fertility, which leads to progress helminth eggs infection (Do et al., 2007). According to Kaliappan et al. (2013) the risk of helminth eggs infection will increase when working in direct contact with the soil. Vegetable vendors are in direct contact with the vegetables. In Buner, Malakand, Lower Dir and Swat districts most of the people are engaged in vegies selling and farming. Agriculture is a potential sector in all these districts. However, based on the preliminary survey conducted by Khan et al.(2017), majority of farmers use night soil to fertilize crops.

Vegetables in one hand are the leading source of essential nutrients, vitamins, minerals, proteins, and fibers but on the other hand when consume raw and improperly washed can transmit pathogens to humans. Vegetables can easily contaminated with parasites during planting, harvesting, packing, transportation and storage due to poor hygienic practices (Sia Su et al., 2012). Unhygienic and low living conditions in developing nations lead to increase the risk of acquiring geohelminth infections.

Many studies have been conducted throughout the world to assess the role of eating fresh uncooked and unwashed vegetables in the transmission of soil-transmitted helminths as: Amol, North of Iran (Siyadatpanah et al., 2013); Kurramabad, Iran (Ezatpour et al., 2013); Zahedan, Iran (Ebrahimzadeh et al., 2013); Benha, Egypt (Eraky et al., 2014) and Lahore, Pakistan (Shafa-Ul-Haq et al., 2014); Jimma Town, Southwest Ethiopia (Tefera et al., 2014); Manglore (Dias et al., 2014); Ebonyi state, Nigeria (Ani and Urom, 2015); Ebonyi state, Nigeria (Iyabo and Oluchi, 2015); Tehran, Iran (Valipour Nouroozi, 2015); Khartoum, state, Sudan (Mohamed et al., 2016); Iran (Mehrnejat et al., 2015) and Lower and Upper Dir districts (Khan et al., 2017). To the best of our knowledge, the data on geo-helminth contamination of vegetables is lacking in province Khyber Pakhtunkhwa, Pakistan, however geohelminth parasites have also been reported in the human beings of different parts of Malaknd region as Pal and Subhani (1989), Nisa et al. (2012), Khan et al. (2011, 2015, 2016, 2017a, b, 2019a, b). The assessing of vegetables contamination and their disinfection has remained a major concern of health 
and therapeutic organizations. Therefore, this study was designed to determine the prevalence of STH contamination of vegetables used raw in the region.

\section{Materials and Methods}

\subsection{Study area}

This research was conducted in Malakand Division, the northwest of Pakistan which comprised an area of nearly $29,800 \mathrm{~km}^{2}$ and has a population of about 6.0 million people. Malakand Division lies latitudes of $35^{\circ} 29^{\prime} 59.99 "$ North and longitudes of $72^{\circ} 00^{\prime} 0.00^{\prime \prime}$ East with $1420 \mathrm{~m}$ in elevation. Of the 7 districts in Malakand division four namely Malakand, Lower Dir, Upper Dir and Swat were selected for the present study. This is a mountainous region with high peaks in the north reaching up to a height of 6000 meters above sea level and the height decreases slowly from north toward south along river Panjkora and river Swat. Karakorum, Hindu Kush and Himalaya form a boundary between the temperate climate, Palearctic zone and subtropical oriental region So the Malakand region is situated in the temperate zone where winters are cold with temperature reaching below the freezing point, while summers are hot and humid due to heavy monsoon rains and the temperature may reach up to $32^{\circ} \mathrm{C}$. The winter season is from mid-November to March and snowfall continues in the upper parts from December to March during which the peaks remain under snow cover.

\subsection{Sample collection}

Twenty five different type of vegetables including: (1) Allium sativum (garlic) (2) Capsicum annum (coriander) (3) Brassica compastris (mustard) (4) Lactuca sativa (lettuce salad) (5) Mentha longifolia (mint) (6) Daucus carota (carrot) (7) Allium cepa (onion) (8) Spinacia oleracea (spinach) (9) Raphanus raphanistrum (raddish) (10) Zingiber officinale (ginger) (11) Solanu tuberosum (potato) (12) Brassica olerace (cabbage) (13) Capsium annum (Chilli) (14) Brassica rapa (turnip) (15) Pisum sativam (peas) (16) Lycopersicon esculentum (Tomato) (17) Colocasia esculenta (taro) (18) Abelmoschus esculantum (Lady finger) (19) Momordica charanjtia (bitter gourd) (20) Solanum melongena (Brinjal) (21) Praecitrullus fistulosus (round gourd) (22) Capsicum annum (green pepper) (23) Cucumis sativus (Cucumber) (24) Luffa cylindrica (vegetable sponge) and (25) Brassica oleracea (cauliflower) were purchased from the selected vegetable markets in all the four districts. A questionnaire comprised on the questions such as educational status of the vendors, type of vegetables, means of display, washed before display was used. In this study fifty vendors participated.

\subsection{Sample processing for parasites}

The collected specimens of vegetables were placed in isolated plastic bags. Each of the bags containing vegetable samples were labeled with a unique number with date of collection. All the samples were brought to the Parasitology Laboratory, Department of Zoology, University of Malakand for screening of parasites. Of about 200 grams of each specimen of vegetables was kept for atleast 15 minutes in physiological solution of one liter in volume. After that the samples were shaken gently with the help of mechanical shaker for upto 20 minutes. After sedimentation about 10 millilitres of the sediment was separated in to a centrifuge tube. The centrifuge tube was centrifuged at $3000 \mathrm{rpm}$ as to get concentrated the parasitic stages (ova, larave and cysts) for about five minutes. After completion of centrifugation, the supernatant was decanted and the sediment was agitated slightly by hand to redistribute the parasitic stages. Finally, the sediment was examined under a light microscope [Labomed 400] using $\times 10$ and $\times 40$ objectives.

\subsection{Statistical analysis}

Graph Pad Prism (version-5) was used for the data analysis. The difference in parasitic contamination among the different categories was compared using one way ANOVA. The p- values were considered to be significant when less than 0.05 .

\section{Results}

Current research pinpoints to understand the prevalence of geo-helminth parasites in vegetable samples commonly sold at main vegetable markets of all the 4 districts of Malakand division, Pakistan. A total of 1942 vegetable samples were screened for the presence of any geohelminth parasite eggs or larval form. Of the examined vegetables only $16.5 \%$ were found contaminated with one or more than one species of geo-helminth parasites. Percentage of each contaminated sample is given according to the order of contamination as: $35.0 \%$ A.sativum (garlic), $30 \% \%$ C. annum (coriander), 27.2\% B.compastris (mustard), $25.6 \%$ L. sativa (lettuce salad), 25.1\% M.longifolia (mint), $26.1 \%$ D.carota (carrot), 23\% A.cepa (onion), 20.1\% S.oleracea (spinach), 20\% R.raphanistrum (reddish), 18.5\% Z.officinale (ginger), 15.6\% S.tuberosum (potato), 13.5\% B.olerace (cabbage), 13\% C. annum (Chilli), 10.2\% B.rapa (turnip), $10.1 \%$ P.sativam (peas), $9.80 \%$ L. esculentum (tomato), $9.33 \%$ C. esculenta (taro), 9.10\% A. esculantum (Lady finger), 9.09\% M.charanjtia (bitter gourd), 8.33\% S.melogena (Brinjal), 7.69\% C. vulgaris (round gourd), 6.94\% C. annum (green bell pepper, $5.26 \%$ C. sativus (Cucumber), $4.16 \%$ L.cylindrica (vegetable sponge) and $4 \%$ B.oleracea (cauliflower). Leafy vegetables examined were found more contaminated $25.1 \%$ followed by root vegetables $21.2 \%$ while fruity veggies were the least contaminated vegetables $9.09 \%$ used. Vegetable samples collected from Malakand were highly contaminated $24.7 \%$ followed by those collected from Swat $18.1 \%$ while vegetable samples examined from Buner and Dir Lower were least contaminated $9.83 \%$ and $8.53 \%$ respectively (Table 1 ).

More than half of the total samples contaminated with single species of parasites $(\mathrm{P}<0.05)$ while the other half with multiple parasitic contamination were also have been investigated. 92 vegetables contained 2 species of parasites $(\mathrm{P}<0.05)$ and 45 with $3(\mathrm{P}>0.05)$ (Table 2$)$.

A.lumbricoides was the commonest geo-helminth found in the studied vegetables followed by hook worm species 
Table 1. Distribution of geo-helminth parasites in relation to the type of vegetables collected from vegetable markets in northwestern parts of Khyber Pakhtunkhwa, Pakistan.

\begin{tabular}{|c|c|c|c|c|c|c|}
\hline & Buner & Malakand & $\operatorname{Dir}(\mathrm{L})$ & Swat & Total & $\%$ \\
\hline \multicolumn{7}{|l|}{ Vegetable type } \\
\hline \multicolumn{7}{|l|}{ Leaf } \\
\hline B. compastris (mustard) & $14 / 4$ & $35 / 14$ & $18 / 4$ & $32 / 5$ & $99 / 27$ & 27.2 \\
\hline L.sativa (lettuce) & $20 / 3$ & $35 / 12$ & $23 / 5$ & 0 & $78 / 20$ & 25.6 \\
\hline S. oleracea (spinach) & $19 / 2$ & $35 / 13$ & $23 / 3$ & $32 / 4$ & $109 / 22$ & 20.1 \\
\hline C. annum (coriander) & $16 / 3$ & $35 / 13$ & $19 / 5$ & 0 & $70 / 21$ & 30 \\
\hline M.longifolia (mint) & $16 / 4$ & $35 / 15$ & $18 / 3$ & $32 / 3$ & $101 / 25$ & 25.1 \\
\hline Sub-total & $85 / 17$ & $175 / 67$ & $101 / 20$ & $96 / 12$ & $457 / 116$ & 25.3 \\
\hline \multicolumn{7}{|l|}{ Fruit } \\
\hline L. esculentum (tomato) & $12 / 0$ & $35 / 7$ & $19 / 2$ & $32 / 1$ & $98 / 10$ & 9.80 \\
\hline C. annum (chilli) & $13 / 1$ & $35 / 8$ & $20 / 0$ & $32 / 4$ & $100 / 13$ & 13 \\
\hline C. sativus (cucumber) & $11 / 0$ & $35 / 4$ & $17 / 0$ & $32 / 3$ & $95 / 5$ & 5.26 \\
\hline A. esculantum (lady finger) & $14 / 1$ & $35 / 6$ & $18 / 1$ & $32 / 1$ & $99 / 9$ & 9.10 \\
\hline P.sativam (peas) & $24 / 1$ & $35 / 8$ & $30 / 0$ & 0 & $89 / 9$ & 10.1 \\
\hline B.olerace (cabbage) & $13 / 1$ & $35 / 5$ & $11 / 2$ & 0 & $59 / 8$ & 13.5 \\
\hline S.melogena (brinjal) & $10 / 1$ & $35 / 6$ & $19 / 0$ & $32 / 1$ & $96 / 8$ & 8.33 \\
\hline B.oleracea (cauliflower) & $9 / 0$ & 0 & $9 / 0$ & $32 / 2$ & $50 / 2$ & 4 \\
\hline C. vulgaris (round gourd) & $13 / 0$ & 0 & $20 / 0$ & $32 / 5$ & $65 / 5$ & 7.69 \\
\hline M.charanjtia (bitter gourd) & $10 / 1$ & 0 & $13 / 1$ & $32 / 3$ & $55 / 5$ & 9.09 \\
\hline L.cylindrica (vegetable sponge) & $9 / 0$ & 0 & $15 / 1$ & 0 & $24 / 1$ & 4.16 \\
\hline C. annum (green bell pepper) & $17 / 1$ & 0 & $23 / 2$ & $32 / 2$ & $72 / 5$ & 6.94 \\
\hline Sub-total & $155 / 7$ & $245 / 44$ & $215 / 9$ & $288 / 22$ & $902 / 82$ & 9.09 \\
\hline \multicolumn{7}{|l|}{ Root } \\
\hline Z.officinale (ginger) & $17 / 3$ & $35 / 8$ & $20 / 2$ & 0 & $72 / 13$ & 18.5 \\
\hline A.sativum (garlic) & $13 / 2$ & $35 / 10$ & $17 / 1$ & $32 / 21$ & $97 / 34$ & 35.0 \\
\hline C. esculenta (taro) & $19 / 1$ & $35 / 5$ & $21 / 2$ & 0 & $75 / 7$ & 9.33 \\
\hline A.cepa (onion) & $16 / 2$ & $35 / 6$ & $17 / 1$ & $32 / 14$ & $100 / 23$ & 23 \\
\hline D.carota (carrot) & $16 / 1$ & $35 / 9$ & $18 / 1$ & $32 / 15$ & $101 / 26$ & 26.1 \\
\hline S.tuberosum (potato) & $16 / 1$ & 0 & $16 / 0$ & $32 / 9$ & $64 / 10$ & 15.6 \\
\hline B.rapa (turnip) & $19 / 2$ & 0 & $20 / 2$ & 0 & $39 / 4$ & 10.2 \\
\hline Reddish & 0 & $35 / 7$ & 0 & 0 & $35 / 7$ & 20 \\
\hline Sub-total & $116 / 11$ & $210 / 45$ & $129 / 9$ & $128 / 59$ & $583 / 124$ & 21.2 \\
\hline Grand-total & $356 / 35$ & $630 / 156$ & $445 / 38$ & $512 / 93$ & $1942 / 322$ & 16.5 \\
\hline$\%$ & 9.83 & 24.7 & 8.53 & 18.1 & & \\
\hline
\end{tabular}

while T.trichura was the least counted nematode in all the vegetable samples. A.lumbricoides, T.trichura and Hookworm was noted $52.1 \%, 14.0 \%$ and $33.8 \%(\mathrm{P}>0.05) ; 55.1 \%, 12.9 \%$ and $31.9 \%(\mathrm{P}>0.05)$ and $55.1 \%, 9.33 \%$ and $35.5 \%(\mathrm{P}>0.05)$ in leaf, fruit and root respectively.

In present study interviews of the vendors have conducted to evaluate the association of parasitic contamination of vegetables in the markets. Vendors were asked about their educational status and it was revealed that $25 \%$ of the vendors had no formal education, $15.1 \%$ had primary education and $13.1 \%$ had secondary education. No significant association was noted between the education level of vendors and the parasitic contamination rate of the vegetables they were selling (see Table 3 ). The association between vegetable collected and that of infected was non-significant (Table 3). Compared to type of vegetable collected garlic was highly infected $35 \%$ while cauliflower showed least $4 \%$ of the parasitic contamination. Significant 
Table 2. Pattern of distribution of geo-helminth contamination of vegetables collected from the vegetable markets in northwestern parts of Khyber Pakhtunkhwa, Pakistan.

\begin{tabular}{|c|c|c|c|c|c|c|}
\hline \multirow{2}{*}{$\begin{array}{l}\text { Pattern of } \\
\text { parasitism }\end{array}$} & \multicolumn{4}{|c|}{ Districts (No. examined /No. infected) } & \multirow{2}{*}{ Total } & \multirow{2}{*}{$\begin{array}{c}\text { P value at } \\
95 \% \mathrm{Cl}\end{array}$} \\
\hline & Peshawar & Malakand & $\operatorname{Dir}(\mathrm{L})$ & Swat & & \\
\hline \multicolumn{7}{|l|}{ Mono-parasitism } \\
\hline Leaf & 9 & 42 & 12 & 8 & $71(22.0)$ & 0.0126 \\
\hline Fruit & 4 & 24 & 5 & 14 & $47(14.5)$ & \\
\hline Root & 7 & 27 & 5 & 28 & $67(20.8)$ & \\
\hline Sub-total & 20 & 93 & 22 & 50 & $185(57.4)$ & \\
\hline \multicolumn{7}{|l|}{ Polyparasitism } \\
\hline \multicolumn{7}{|l|}{ Double } \\
\hline Leaf & 4 & 17 & 5 & 3 & $29(9.00)$ & 0.0313 \\
\hline Fruit & 2 & 14 & 2 & 5 & $23(7.14)$ & \\
\hline Root & 3 & 15 & 3 & 19 & $40(12.4)$ & \\
\hline Sub-total & 9 & 46 & 10 & 27 & $92(28.5)$ & \\
\hline \multicolumn{7}{|l|}{ Triple } \\
\hline Leaf & 4 & 8 & 3 & 1 & $16(4.96)$ & 0.4031 \\
\hline Fruit & 1 & 6 & 2 & 3 & $12(3.72)$ & \\
\hline Root & 1 & 3 & 1 & 12 & $17(5.27)$ & \\
\hline Sub-total & 6 & 17 & 6 & 16 & 45(13.9) & \\
\hline Grand-total & 35 & 156 & 38 & 93 & $322(16.5)$ & \\
\hline Total samples studied & 356 & 630 & 445 & 512 & 1942 & \\
\hline
\end{tabular}

Table 3. Overall prevalence of geo-helminth parasites in fresh vegetables collected from vegetable markets in northwestern parts of Khyber Pakhtunkhwa, Pakistan.

\begin{tabular}{|c|c|c|c|c|c|c|}
\hline \multirow[b]{2}{*}{ Type of vegetable } & \multicolumn{4}{|c|}{ Districts (No.examined /No.infected) } & \multirow[b]{2}{*}{ Total } & \multirow{2}{*}{$\begin{array}{c}\text { P value a } \\
95 \% \mathrm{Cl}\end{array}$} \\
\hline & $\begin{array}{c}\text { Peshawar } \\
(\mathbf{n}=\mathbf{3 4 0})\end{array}$ & $\begin{array}{c}\text { Malakand } \\
(\mathrm{n}=630)\end{array}$ & $\begin{array}{c}\operatorname{Dir}(L) \\
(n=445)\end{array}$ & Swat $(n=512)$ & & \\
\hline \multicolumn{7}{|l|}{ Leaf } \\
\hline Ascaris lumbricoides & 13 & 61 & 25 & 12 & $111(52.1)$ & 0.0906 \\
\hline Trichuris trichura & 6 & 14 & 5 & 5 & $30(14.0)$ & \\
\hline Hook worm & 16 & 37 & 13 & 6 & $72(33.8)$ & \\
\hline Sub-total & 35 & 112 & 43 & 23 & $213(36.4)$ & \\
\hline \multicolumn{7}{|l|}{ Fruit } \\
\hline Ascaris lumbricoides & 7 & 38 & 10 & 26 & $81(55.1)$ & 0.0693 \\
\hline Trichuris trichura & 2 & 13 & 2 & 2 & $19(12.9)$ & \\
\hline Hook worm & 5 & 28 & 6 & 8 & 47 (31.9) & \\
\hline Sub-total & 14 & 79 & 18 & 36 & $147(25.1)$ & \\
\hline \multicolumn{7}{|l|}{ Root } \\
\hline Ascaris lumbricoides & 11 & 39 & 10 & 64 & $124(55.1)$ & 0.1652 \\
\hline Trichuris trichura & 4 & 4 & 1 & 12 & $21(9.33)$ & \\
\hline Hook worm & 10 & 29 & 9 & 32 & $80(35.5)$ & \\
\hline Sub-total & 25 & 72 & 20 & 108 & $225(38.4)$ & \\
\hline Grand-total & 74 & 263 & 81 & 167 & 585 & \\
\hline
\end{tabular}


association was found among the each type (part) of vegies and parasitic contamination. Regarding the factor means of display of the vegetables $(0.0561, \mathrm{P}<0.05)$ wash before display 0.1777 (see Table 4).

\section{Discussion}

As the names indicated that soil transmitted helminthes are those that require soil for the development of their

Table 4. Factors associated with geo-helminth contamination of vegetables sold at vegetable markets in northwestern parts of Khyber Pakhtunkhwa, Pakistan.

\begin{tabular}{|c|c|c|c|c|}
\hline \multirow{2}{*}{ Variable } & \multicolumn{4}{|c|}{ Results of geo-helminth analysis } \\
\hline & Total & Positive (\%) & 95\% Cl (level) & P value \\
\hline \multicolumn{5}{|l|}{ Educational status of vendors } \\
\hline No formal education & 367 & $92(25.0)$ & -195.86 to 1275.9 & 0.1113 \\
\hline Primary education & 1172 & $177(15.1)$ & & \\
\hline Secondary education & 403 & $53(13.1)$ & & \\
\hline \multicolumn{5}{|l|}{ Total } \\
\hline \multicolumn{5}{|l|}{ Vegetable } \\
\hline \multicolumn{5}{|l|}{ Leaf } \\
\hline Brassica compastris (mustard) & 99 & $27(27.2)$ & 51.057 to 85.743 & $<0.0001$ \\
\hline Lectuca sativa (lettuce salad) & 78 & $20(25.6)$ & & \\
\hline Solanum oleracea (spinach) & 109 & $22(20.1)$ & & \\
\hline Corriandrum annum (coriander) & 70 & $21(30)$ & & \\
\hline Mentha longifolia (mint) & 101 & $25(25.1)$ & & \\
\hline \multicolumn{5}{|l|}{ Fruit } \\
\hline L. esculentum (tomato) & 98 & $10(9.80)$ & 53.518 to 83.482 & $<0.0001$ \\
\hline C. annum (chilli) & 100 & $13(13)$ & & \\
\hline C. sativus (cucumber) & 95 & $5(5.26)$ & & \\
\hline A. esculantum (lady finger) & 99 & $9(9.10)$ & & \\
\hline P.sativam (peas) & 89 & $9(10.1)$ & & \\
\hline B.olerace (cabbage) & 59 & $8(13.5)$ & & \\
\hline S.melogena (brinjal) & 96 & $8(8.33)$ & & \\
\hline B.oleracea (cauliflower) & 50 & $2(4)$ & & \\
\hline C. vulgaris (round gourd) & 65 & $5(7.69)$ & & \\
\hline M.charanjtia (bitter gourd) & 55 & $5(9.09)$ & & \\
\hline L.cylindrica (vegetable sponge) & 24 & $1(4.16)$ & & \\
\hline C. annum (green bell pepper) & 72 & $5(6.94)$ & & \\
\hline \multicolumn{5}{|l|}{ Root } \\
\hline Z.officinale (ginger) & 72 & $13(18.5)$ & 35.931 to 78.819 & $<0.0001$ \\
\hline A.sativum (garlic) & 97 & $34(35.0)$ & & \\
\hline C. esculenta (taro) & 75 & $7(9.33)$ & & \\
\hline A.cepa (onion) & 100 & $23(23)$ & & \\
\hline D.carota (carrot) & 101 & $26(26.1)$ & & \\
\hline S.tuberosum (potato) & 64 & $10(15.6)$ & & \\
\hline B.rapa (turnip) & 39 & $4(10.2)$ & & \\
\hline Reddish & 35 & $7(20)$ & & \\
\hline \multicolumn{5}{|l|}{ Means of display } \\
\hline On the floor & 1041 & $193(18.5)$ & -22.665 to 1102.7 & 0.0561 \\
\hline On the top of tables & 487 & $78(16.0)$ & & \\
\hline On the wheel barrow & 414 & $51(12.3)$ & & \\
\hline \multicolumn{5}{|l|}{ Washed before display } \\
\hline Yes & 1366 & $193(14.1)$ & -895.25 to 2515. & 0.1777 \\
\hline No & 576 & $129(22.3)$ & & \\
\hline
\end{tabular}


infective stages as like that of eggs in case of A.lumbricoides and T.trichura and larvae in case of hookworm species. Vegetables play a significant role in sustaining and development and then transferring of these infective forms of parasites in to the consumers (Khan et al., 2017).

In current research, we screened 1942 samples of twenty five types of vegetables purchased from main vegetable markets in 4 districts of Khyber Pakhtunkhwa, Pakistan for the presence of any geo-helminth parasite contamination. Of the examined vegetables only $16.5 \%$ ( $n=322 / 1942)$ were found contaminated with single or multiple geo-helminths. Recently, Khan et al. (2017) examined 520 samples of thirteen different types of fresh vegetables from two main vegetable markets in lower Dir and Upper Dir districts in Khyber Pakhtunkhwa, Pakistan, of which $10.7 \%$ were positive for helminth eggs and Entamoeba histolytica cysts.

Current research agreed with the findings conducted in Khartoum, state, Sudan 13.5\% (Mohamed et al., 2016) and Lower and Upper Dir districts 10.7\% (Khan et al., 2017); Benha, Egypt 29.6\% (Eraky et al., 2014) and Lahore, Pakistan 31.2\% (Shafa Ul-Haq et al., 2014). Studies conducted in Jimma Town, Southwest Ethiopia 58.7\% (Tefera et al., 2014); Amol, North of Iran 46.5\% (Siyadatpanah et al., 2013); Zahedan, Iran 44.8\% (Ebrahimzadeh et al., 2013); Manglore 42\% (Dias et al., 2014); Iran 48.4\% (Mehrnejat et al., 2015); Ebonyi state, Nigeria 60\% (Ani and Urom, 2015); Kurramabad, Iran 52.7\% (Ezatpour et al., 2013) and Ebonyi state, Nigeria 55\% (Iyabo and Oluchi, 2015) showed highest rate of parasitic contamination. The research conducted in Tehran, Iran 8.5\% (Valipour Nouroozi, 2015) revealed the low rate of parasitic contamination in fresh vegetables. Highest prevalence $73.2 \%$ of soil transmitted helmnthiasis in different occupational groups of Swat, Pakistan was reported by Khan et al. (2017).

In present study, 52.1\%, 55.1\% and 55.1\% of the leaf, fruit and root respectively of fresh vegetables were found contaminated with Ascaris lumbricoides eggs, the most common parasite detected. Findings of the present research agrees with the studies conducted in Nigeria 54.5\% (Elom et al., 2012); Tripoli-Libya 68\% (Abougrain et al., 2010); Swat, Pakistan 53\% (Khan et al., 2017); Lahore, Pakistan 37.1\% (Shafa Ul- Haq et al., 2014); Lower and Upper Dir districts, Pakistan 26.7\% (Khan et al., 2017). This geo-helminth parasite has wide range of distribution with variable rate of prevalence as Nigeria 23.8\% (Iyabo and Oluchi, 2015); Manglore 23\% (Dias et al., 2014); Eastern Showa, Ethiopia 22.2\% (Benti and Gemechu 2014); Tabuk, Saudi Arabia 21.7\% (Gabre and Shakir, 2016); and Ebonyi state, Nigeria 20.4\% (Ani and Urom, 2015); Jimmu town Southeast Ethiopia 6.7\% (Tefera et al., 2014); Zahedan Iran 6.1\% (Ebrahimzadeh et al., 2013); Kogi state, Nigeria 5.6\% (Lyaji and Agahiu, 2016); Khurram abad, Iran 4.7\% (Ezatpour et al., 2013);); Khartoum state, Sudan 2.9\% (Mohamed et al., 2016); Tukkey 2.0\% (Avcioğlu et al., 2011) and Benha Egypt 0.6\% (Eraky et al., 2014).

Hook worms species was the second most prevalent parasite $33.8 \%, 31.9 \%$ and $35.5 \%$ reported in the present study in leaf, fruit and root respectively, which was comparable with the findings of Abakaliki Nigeria, 23.8\% (Elom et al., 2102); Ebonyi state, Nigeria 24.8\% (Ani and Urom, 2015) and Ebonyi state, Nigeria 33.3\% (Iyabo and
Oluchi, 2015). Some variable rate of contamination was also been reported in different parts of the world as Manglore 9.52\% (Dias et al., 2014); Accra, Ghana 13\% Duedu et al. (2014) and Lahore, Pakistan 10.8\% (Shafa Ul Haq et al., 2014); Kogi state, Nigeria 5.3\% (Lyaji and Agahiu 2016) and Khartoum, state, Sudan 5.7\% (Mohamed et al., 2016).

Contamination rate of Trichuris trichura was 14\%, 12.9\% and $9.33 \%$ in the present research, which can be compare with studies reported in Ebonyi state, Nigeria 18.6\% (Ani and Urom, 2015); Lower and Upper Dir districts 19.6\% (Khan et al., 2017) and Ebonyi state, Nigeria 9.52\% (Iyabo and Oluchi, 2015); Manglore 9.52\% larvae (Dias et al., 2014); Ebonyi state Southeast Nigeria 8.90\% (Elom et al., 2012); Lahore, Pakistan 6.41\% (Shafa Ul Haq et al., 2014). This nematode was observed in lowest rate of prevalence as Khartoum, state, Sudan 2.9\% (Mohamed et al., 2016); Accra, Ghana 2\% Duedu et al. (2014); Kogi state Nigeria 1.4\% (Lyaji and Agahiu 2016); Zahidan Iran 1\% (Ebrahimzadeh et al., 2013). This nematode is variable in prevalence with a wide range of geographic distribution.

Present study showed more than half $57.4 \%$ ( $n=185 / 322$ ) of the vegetables were found contaminated with single geo-helminth species and multiple geo-helminthiasis revealed $28.5 \%(n=92 / 322)$ double and $13.9 \%(n=45 / 322)$ triple pattern of parasitic contamination. According to Beke et al., 2017 more than half 45.6\% ( $n=164 / 360)$ of the vegetables screened for parasitic contamination were found contaminated with single while other $8.88 \%$ $(n=32 / 360)$ were with more than one species of parasites. The multiple parasite contamination in vegetables used routinely is needed to be studied thoroughly.

Highest and lowest rate of parasitic contamination found in different vegetables screened in different parts of the world by different workers as garlic and cauliflower $35 \%$ and $4 \%$ (present study); coriander and ginger $14.2 \%$ and 1.78\% Lower and Upper Dir districts, Pakistan (Khan et al., 2017); leek and green onion $80 \%$ and $34.5 \%$ Khoramabad, Iran (Ezatpour et al., 2013); lettuce and cucumber 28.6\% and 11.1\% Ebonyi State, Nigeria (Ani and Urom, 2015); lettuce and chilli 48\% and 16\% Lahore, Pakistan (ShafaUl-Haq et al., 2014); tomato and okro 20.9\% and 10.2\% Kogi State, Nigeria (Lyaji and Agahiu, 2016);cucumber and tomato $15.7 \%$ and $2.72 \%$ Tabuk, Saudi Arabia (Gabre and Shakir, 2016);lettuce and cabbage $61 \%$ and $18 \%$ Accra, Ghana (Duedu et al., 2014); lettuce and leek 45.5\% and 10.5\% Benha, Egypt (Eraky et al., 2014); spinach and coriander $17.2 \%$ and 3.2\% Amol, North of Iran (Siyadatpanah et al., 2013) respectively.

\section{Conclusions}

This study evidenced that vegetables eating raw are the potential source of transmission for geo-helminth parasites to humans if and when consumed without proper cleaning and or cooking. A comprehensive health education should be given to vendors and farmers of vegetables and to the general population on the health risks associated with consumption of contaminated vegetables. The consumers should always observe the basic principle of food and personal hygiene that is thorough washing of vegetables before eating and washing hands before meal. 


\section{Acknowledgments}

The authors acknowledge the assistance of farmers and vendors during collection and data information. The authors also extend their appreciation to the researchers supporting project number (RSP-2020/94) King Saud University Riyadh, Saudi Arabia.

\section{References}

ABOUGRAIN, A.K., NAHAISI, M.H., MADI, N.S., SAIED, M.M. and GHENGHESH, K.S., 2010. Parasitological contamination in salad vegetables in Tripoli-Libya. Food Control, vol. 21, no. 5, pp. 760-762. http://dx.doi.org/10.1016/j.foodcont.2009.11.005.

ANI, O.C. and UROM, E., 2015. Parasites contamination of salad vegetables sold in Abakaliki, Ebonyi state, Nigeria. Animal Research International, vol. 12, no. 2, pp. 2212-2217.

AVCIOĞLU, H., SOYKAN, E. and TARAKCI, U., 2011. Control of helminth contamination of raw vegetables by washing. Vector Borne and Zoonotic Diseases (Larchmont, N.Y.), vol. 11, no. 2, pp. 189-191. http://dx.doi.org/10.1089/vbz.2009.0243. PMid:20569015.

BENTI, G. and GEMECHU, F., 2014. Parasitic contamination on vegetables irrigated with awash river in selected farms, Eastern Showa, Ethiopia.J Parasitol Vector Biol, vol. 5, no. 7, pp. 103-109. http://dx.doi.org/10.5897/JPVB2014.0150.

BLACKBURN, C. and MCCLURE, P.J., 2002. Foodborne pathogens: hazards, risk analysis and control. Washington DC: CRC Press, pp. 18-919. http://dx.doi.org/10.1201/9781439832837.

DIAS, M., GEORGE, M. and DIAS, A., 2014. How safe are vegetables: parasitological contamination of fresh leafy vegetables in Manglore. International Journal of Applied Biology and Pharmaceutical Technology, vol. 5, no. 4, pp. 80-82.

DIRECTORATE GENERAL OF DISEASE PREVENTION - DGDP. ENVIRONMENTAL HEALTH MINISTRY OF HEALTH OF THE REPUBLIC OF INDONESIA - EHMHRI, 2013. Profile disease control and environmental sanitation year 2012. Jakarta: DGDP/EHMHRI.

DO, T.T., MøLBAK, K., PHUNG, D.C. and DALSGAARD, A., 2007. Helminth infections among people using wastewater and human excreta in peri-urban agriculture and aquaculture in Hanoi, Vietnam. Tropical Medicine E International Health, vol. 12, suppl. 2, pp. 82-90. http://dx.doi.org/10.1111/j.13653156.2007.01945.x. PMid:18005319.

DUEDU, K.O., YARNIE, E.A., TETTEH-QUARCOO, P.B., ATTAH, S.K., DONKOR, E.S. and AYEH-KUMI, P.F., 2014. A comparative survey of the prevalence of human parasites found in fresh vegetables sold in supermarkets and open-aired markets in Accra, Ghana. BMC Research Notes, vol. 7, no. 1, pp. 836. http:// dx.doi.org/10.1186/1756-0500-7-836.

EBRAHIMZADEH, A., JAMSHIDI, A. and MOHAMMADI, S., 2013. The parasitic contamination of raw vegetables consumed in Zahedan, Iran. Health Scope, vol. 1, no. 4, pp. 205-209. http:// dx.doi.org/10.17795/jhealthscope-8209.

ELOM, M.O., EZE, U.A., NWORIE, A. and AKPOTOMI, I.O., 2012. Prevalence of geohelminths on edible fruits and vegetables cultivated in rural villages of Ebonyi State, South East Nigeria. American Journal of Food and Nutrition, Vol. 2, No. 3, pp. 58-64. http://dx.doi.org/10.5251/ajfn.2012.2.3.58.64.

ERAKY, M.A., RASHED, S.M., NASR, M.E.S., EL-HAMSHARY, A.M.S. and SALAH EL-GHANNAM, A., 2014. Parasitic contamination of commonly consumed fresh leafy vegetables in Benha, Egypt.
Journal of Parasitology Research, vol. 2014, pp. 613960. http:// dx.doi.org/10.1155/2014/613960. PMid:25024845.

EZATPOUR, B., CHEGENI, A.S., ABDOLLAHPOUR, F., AAZAMI, M. and ALIREZAEI, M., 2013. Prevalence of parasitic contamination of raw vegetables in Khorramabad, Iran. Food Control, vol. 34, no. 1, pp. 92-95. http://dx.doi.org/10.1016/j.foodcont.2013.03.034.

GABRE, R.M. and SHAKIR, A., 2016. Prevalence of some human enteroparasites in commonly consumed raw vegetables in Tabuk, Saudi Arabia. Journal of Food Protection, vol. 79, no. 4, pp. 655-658. http://dx.doi.org/10.4315/0362-028X.JFP-15-485.

IYABO, U.B. and OLUCHI, U.R., 2015. Geohelminth contamination of common fruits and vegetables in Ebonyi State, Nigeria: the public health implication. Aascit Journal Of Bioscience, vol. 1, no. 2, pp. 15-19.

KALIAPPAN, S.P., GEORGE, S., FRANCIS, M.R., KATTULA, D., SARKAR, R., MINZ, S., MOHAN, V.R., GEORGE, K., ROY, S., AJJAMPUR, S.S.R., MULIYIL, J. and KANG, G., 2013. Prevalence and clustering of soil-transmitted helminth infections in a tribal area in southern I ndia. Tropical Medicine E' International Health, vol. 18, no. 12, pp. 1452-1462. http://dx.doi.org/10.1111/tmi.12205. PMid:24237860.

KHAN, W., IMRAN and WAHAB, A., 2016. Intestinal obstruction by Ascaris lumbricoides in a 12 year Old Boy: a case report in Pakistan. Journal of Bacteriology \& Parasitology, vol. 7, no. 1, pp. 262. http://dx.doi.org/10.4172/2155-9597.1000262.

KHAN, W., KHAN, N.I., BUKHARI, S.N.F. and BEGUM, N., 2019a. Prevalence of intestinal parasitic infection among drug addicts in District Swat, Khyber Pakhtunkhwa, Pakistan. Iranian Journal of Parasitology, vol. 14, no. 2, pp. 359-361. PMid:31543928.

KHAN, W., KHAN, J., KHAN,N., IQBAL, R., ULLAH, A., GHAFFAR, R., MEHMOOD, S.A., AHMAD, S., KHAN, S. and ULLAH, F. 2019b. Soil-transmitted helminth infections in school children of three districts of Malakand region, Khyber Pakhtunkhwa, Pakistan. Pakistan Journal of Pharmaceutical Sciences, vol. 32, no. 2, suppl., pp. 799-803. PMID: 31103975.

KHAN, W., MUMTAZ, G., BIBI, S. and AFZAL, S., 2017. Parasitic contamination of fresh vegetables sold at upper and lower Dir Districts, Khyber Pakhtunkhwa, Pakistan. Pakistan Journal of Zoology, vol. 49, no. 3, pp. 1115-1118. http://dx.doi.org/10.17582/ journal.pjz/2017.49.3.sc3.

KHAN, W., NISA, N. and KHAN, A., 2011. An investigation of incidence of intestinal parasites in under and above 15 years age in farmers of Swat, Pakistan. Proceedings of Parasitology, vol. 52, pp. 43-53.

KHAN, W., NISA, N. and KHAN, A., 2015. Diversity of intestinal parasites in male and female students and workers of education Department of Swat, Pakistan. Pakistan Journal of Zoology, vol. 47, no. 2, pp. 565-568.

KHAN, W., NISA, N. and KHAN, A., 2017a. Soil transmitted helminthiasis in different occupational groups in Swat, Khyber Pakhtunkhwa, Pakistan. Pakistan Journal of Pharmaceutical Sciences, vol. 3, no. 4, pp. 1345-1350. PMid:29039336.

KHAN, W., NISA, N. and KHAN, A., 2017b. Prevalence and risk factors associated with intestinal parasitic infections among Food Handlers of Swat, Khyber Pakhtunkhwa, Pakistan. Journal of Food and Nutrition Research, vol. 5, no. 5, pp. 331-336. http:// dx.doi.org/10.12691/jfnr-5-5-7.

KOZAN, E., GONENC, B., SARIMEHMETOGLU, O. and AYCICEK, H., 2005. Prevalence of helminth eggs on raw vegetables used for salads. Food Control, vol. 16, no. 3, pp. 239-242. http://dx.doi. org/10.1016/j.foodcont.2004.02.005.

LYAJI, F. O. and AGAHIU, E. E., 2016. Contamination on helminth parasites on fruits sold in anyigba, Kogi State, Nigeria. Scholarly Journal of Agricultural Science, vol. 6, no. 6, pp. 195-199. 
MASCARINI-SERRA, L., 2011. Prevention of soil-transmitted helminth infection. Journal of Global Infectious Diseases, vol. 3, no. 2, pp. 175182. http://dx.doi.org/10.4103/0974-777X.81696. PMid:21731306.

MEHRNEJAT, N., KADKHODAIE, S., FARROKHZADEH, H., YOUSEFI, H.A., POURGHEYSARI, H. and SEYF, S., 2015. Evaluation of parasitic contamination in consuming vegetables in a city of Iran in 2011. International Journal of Environmental Health Engineering, vol. 4, no. 1, pp. 25.

MOHAMED, M.A., SIDDIG, E.E., ELAAGIP, A.H., EDRIS, A.M.M. and NASR, A.A., 2016. Parasitic contamination of fresh vegetables sold at central markets in Khartoum state, Sudan. Annals of Clinical Microbiology and Antimicrobials, vol. 15, no. 1, pp. 17. http://dx.doi.org/10.1186/s12941-016-0133-5.

NISA, N., KHAN, W. and KHAN, A., 2012. A Prevalence of intestinal parasites in male and female shepherds of Swat, Pakistan. International Journal of Biology and Biotechnology, vol. 8, no. 4, pp. 597-603.

PAL, R.A. and SUBHANI, F., 1989. Prevalence of intestinalhelminth parasites in primary school children of Dir District (NWFP). Pakistan J. Sci. Tech, vol. 13, pp. 99-102.

PULLAN, R.L., SMITH, J.L., JASRASARIA, R. and BROOKER, S.J., 2014. Global numbers of infection and disease burden of soil transmitted helminth infections in 2010. Parasites \& Vectors, vol. 7, no. 1, pp. 37. http://dx.doi.org/10.1186/1756-3305-7-37. PMid:24447578.

SHAFA-UL-HAQ, S., MAQBOOL, A., JAVED, K.U., YASMIN, G. and SULTANA, R., 2014. Parasitic contamination of vegetables eaten raw in Lahore, Pakistan. Pakistan Journal of Zoology, vol. 46, pp. 130-135.

SHUMBEJ, T., BELAY, T., MEKONNEN, Z., TEFERA, T. and ZEMENE, E., 2015. Soil-transmitted helminths and associated factors among pre-school children in Butajira Town, South-Central Ethiopia: a community-based cross-sectional study. PLoS One, vol. 10, no. 8, pp. e0136342. http://dx.doi.org/10.1371/journal. pone.0136342. PMid:26305361.

SIA SU, G.L., MARIANO, C.M.R., MATTI, N.S.A. and RAMOS, G.B., 2012. Assessing parasitic infestation of vegetables in selected markets in Metro Manila, Philippines. Asian Pacific Journal of Tropical Disease, vol. 2, no. 1, pp.51-54. http://dx.doi.org/10.1016/ S2222-1808(12)60012-7.

SIYADATPANAH, A., TABATABAEI, F., EMAMI ZEYDI, A., SPOTIN, A., FALLAH-OMRANI, V., ASSADI, M., MORADI, S., ROSTAMI, A., MEMARI, F. and HAJIALIANI, F., 2013. Parasitic contamination of raw vegetables in Amol, North of Iran. Archives of Clinical Infectious Diseases, vol. 8, no. 2, pp. 1-4. http://dx.doi.org/10.5812/ archcid.15983.

SUCHDEV, P.S., RUTH, L.J., ODERO, K., NJENGA, S.M., KANYI, H., WIEGAND, R.E., BARTOCES, M., DAVIS, S.M., MONTGOMERY, J.M., FOX, L.A.M. and WORRELL, C.M., 2014. Soil-transmitted helminth infection and nutritional status among urban slum children in Kenya. The American Journal of Tropical Medicine and Hygiene, vol. 90, no. 2, pp. 299-305. http://dx.doi.org/10.4269/ ajtmh.13-0560. PMid:24343884.

TEFERA, T., BIRUKSEW, A., MEKONNEN, Z. and ESHETU, T., 2014. Parasitic contamination of fruits and vegetables collected from selected local markets of Jimma Town, Southwest Ethiopia. International Scholarly Research Notices, vol. 382715, pp. 382715. http://dx.doi.org/10.1155/2014/382715. PMid:27355069.

VALIPOUR NOUROOZI, R., 2015. Detection of parasitic contamination in ready to eat fresh packaged herbs sold in Tehran, Iran. Journal of Community Health Research, vol. 4, no. 2, pp. 99-104.

WHO, 2017. Base line survey report of soil-transmitted helminths prevalence in Pakistan. WHO, the Indus hospitals, Institute of Development and economic alternatives, and evidence action, pp 1-79. 


\section{BRAZILIAN JOURNAL OF BIOLOGY}

Erratum

\section{ERRATUM}

In the article "Evaluation of vegetables grown in dry mountainous regions for soil transmitted helminths contamination”, DOI: http://dx.doi.org/10.1590/1519-6984.238953, published in Braz. J. Biol. vol.82 São Carlos 2022 Epub March 12, 2021, in the section:

Where it reads:

Notes and Comments

It should be read:

Original Article 